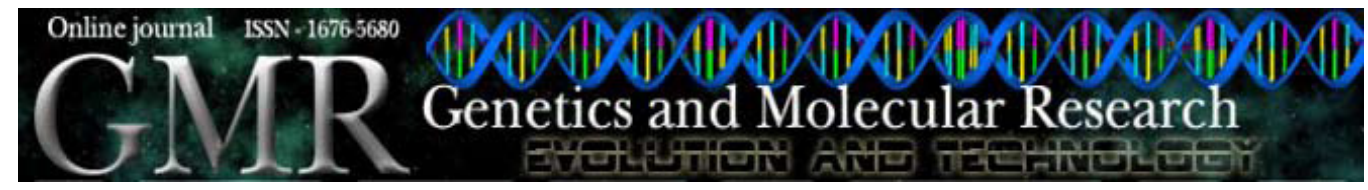

\title{
An efficient method for DNA extraction from Cladosporioid fungi
}

\author{
M.A. Moslem ${ }^{1}$, A.H. Bahkali ${ }^{1}$, K.A. Abd-Elsalam ${ }^{1,2}$ and P.J.G.M. Wit ${ }^{3}$ \\ ${ }^{1}$ College of Science, Botany and Microbiology Department, \\ King Saud University, Riyadh, Saudi Arabia \\ ${ }^{2}$ College of Science, Abdul Rahman Al-Jeraisy DNA Research Chair, \\ King Saud University, Riyadh, Saudi Arabia \\ ${ }^{3}$ Laboratory of Phytopathology, Wageningen University, Wageningen, \\ The Netherlands \\ Corresponding author: K.A. Abd-Elsalam \\ E-mail: kamel200@ksu.edu.sa
}

Genet. Mol. Res. 9 (4): 2283-2291 (2010)

Received July 26, 2010

Accepted September 23, 2010

Published November 23, 2010

DOI 10.4238/vol9-4gmr936

\begin{abstract}
We developed an efficient method for DNA extraction from Cladosporioid fungi, which are important fungal plant pathogens. The cell wall of Cladosporioid fungi is often melanized, which makes it difficult to extract DNA from their cells. In order to overcome this we grew these fungi for three days on agar plates and extracted DNA from mycelium mats after manual or electric homogenization. Highquality DNA was isolated, with an $\mathrm{A}_{260} / \mathrm{A}_{280}$ ratio ranging between 1.6 and 2.0. Isolated genomic DNA was efficiently digested with restriction enzymes and produced distinct banding patterns on agarose gels for the different Cladosporium species. Clear DNA fragments from the isolated DNA were amplified by PCR using small and large subunit rDNA primers, demonstrating that this method provides DNA of sufficiently high quality for molecular analyses.
\end{abstract}

Key words: DNA extraction; Cladosporium spp; PCR; rDNA-ITS1 


\section{INTRODUCTION}

Cladosporioid hyphomycetes are common, widespread dematiaceous fungi that can be isolated from the environment almost anywhere in the world (Yano et al., 2003; Schubert, 2005). The most common species of the genus Cladosporium include Cladosporium herbarum, C. sphaerospermum, C. cladosporioides, and C. elatum (Qiu-Xia et al., 2008). The genus contains many saprophytic and some pathogenic species and several species are used in industry as efficient biodegraders of aromatic compounds. In spite of the importance of Cladosporium in medicine, agriculture and industry, very few molecular and phylogenic data are available from this cosmopolitan group of fungi (Ghahfarokhi et al., 2004). Good-quality DNA is required to perform conventional polymerase chain reaction (PCR) for phylogenic analyses with specific primers (Pitkäranta et al., 2008). The cell walls of Cladosporium species are often melanized, which makes difficult to disrupt them for extraction of DNA. Cell disruption for DNA extraction from this type of fungi can be achieved after freeze-thawing or treatment with liquid nitrogen or dry ice (Loeffler et al., 2001; Griffin et al., 2002). Incubation of mycelium with cocktails of cell-wall degrading enzymes prior to DNA extraction is also frequently used (Williamson et al., 2000). Melanized cell walls contain complex polysaccharides and various secondary metabolites, including complex phenolic compounds, which hamper successful isolation of DNA (Rogers, 1994). These cell wall properties require rigorous techniques to isolate DNA from these fungi (Yeo and Wong, 2002) compared to mammalian cells (Wong et al., 2007). Due to the complexity of these fungal cell walls, conventional methods employed for extracting DNA are often not suitable (Karakousis et al., 2006). Liquid nitrogen is often not available at remote locations and a method for DNA extraction that does not require liquid nitrogen would be useful (Sharma et al., 2003). The need for a rapid and efficient method is urgent, especially when hundreds of samples need to be analyzed. This is especially true for the analysis of Cladosporium species that occur worldwide and are of medical and economic importance. For this purpose, we describe here a rapid and efficient method for extraction of DNA that can be used for molecular analyses including PCR.

\section{MATERIAL AND METHODS}

\section{Cladosporium isolates}

Nine different species of Cladosporium were used in this study. Five species were obtained from the Saudi MycoBank (SMB) of King Saud University (Riyadh) including Cladosporium herbarum (Persoon) Link, C. macrocarpum Preuss., C. chlamydosporis Matsushima, C. fulvum Cooke, and Cladosporium sp and four were obtained from the Centraalbureau voor Schimmelcultures, Utrecht, The Netherlands (CBS) including C. cladosporioides (CBS 131.29), C. herbarum (CBS 673.69), C. sphaerospermum (CBS 114326), and C. tennuissimum (CBS 117134).

\section{Fungal growth on duplex media}

We used Petri dishes instead of liquid shake cultures to grow the different species for DNA isolation. Disposable polystyrene Petri dishes $(4 \mathrm{~cm})$ were filled with $1800 \mu \mathrm{L}$ solid medium (potato dextrose agar), on which a layer of liquid medium (1400 $\mu \mathrm{L}$ peptone yeast 
glucose) was added. The fungal species isolates were cultured by inoculating a small mycelial disk from stock onto the prepared Petri dishes that were subsequently incubated for $2-3$ days at $28^{\circ} \mathrm{C}$. Mycelium was lifted from the medium using sterilized inoculating loops and transferred into sterile $1.5-\mathrm{mL}$ microfuge tubes. For some fungal species, the mycelium mats were pelleted by centrifugation for $15 \mathrm{~min}$ at $4000 \mathrm{~g}$ in a deepwell swing-bucket rotor (microcenrifuge $5804 \mathrm{R}$; Eppendorf).

The mycelium pellet was washed with $600 \mu \mathrm{L}$ TE buffer and centrifuged again for 5 $\min$ at $4000 \mathrm{~g}$. Finally, the TE buffer was decanted.

\section{Fungal mat homogenization and DNA isolation}

A hand-operated or electric grinder (Retsch, Germany) was used to homogenize fresh mycelial mats in a $1.5-\mathrm{mL}$ microfuge tube. To prevent cross-contamination, the pestle tip was cleaned between isolations (the pestle tip was immersed in $70 \% \mathrm{EtOH}$ and the grinder was turned on for $3 \mathrm{~s}$ and subsequently the pestle tip was rinsed in sterile distilled water and dried with sterilized filter paper. The step-by-step DNA isolation procedure is shown in Table 1.

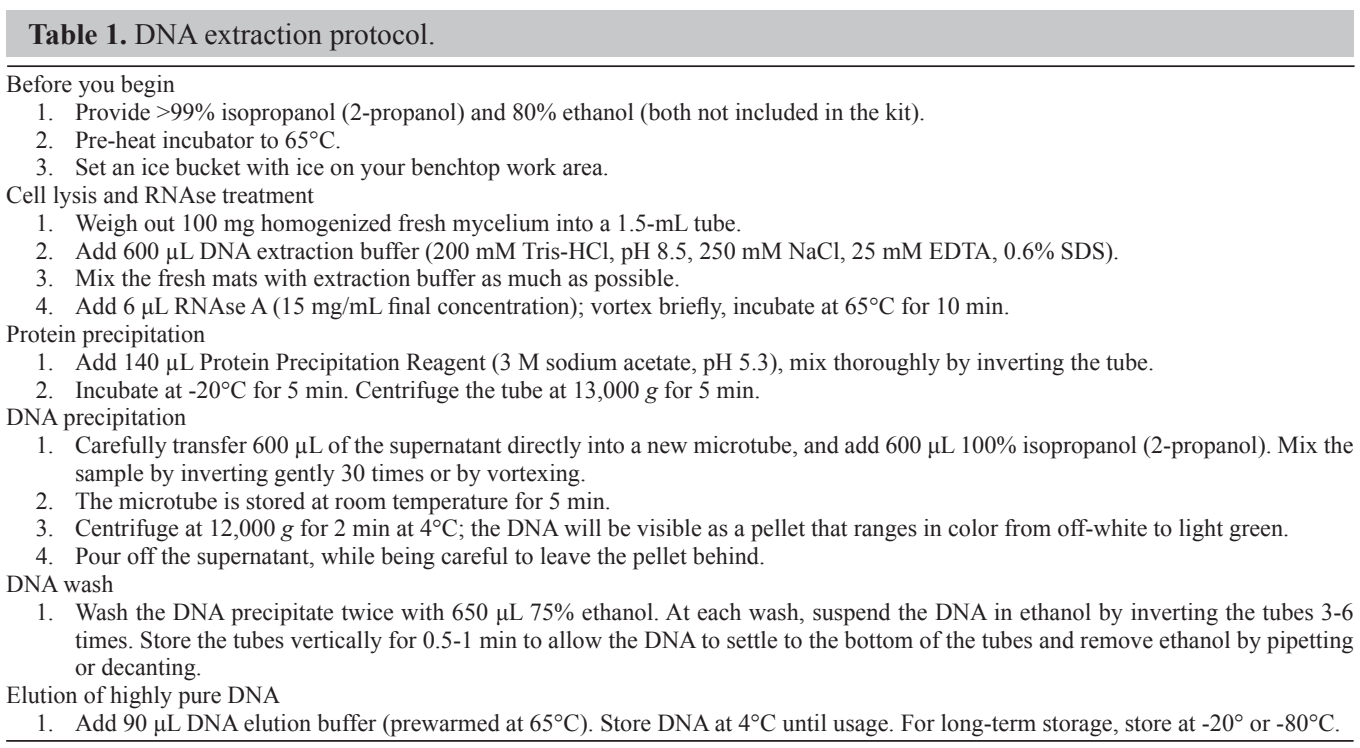

\section{DNA quantification}

DNA was quantified either by a) measuring the absorbance at $260 \mathrm{~nm}\left(\mathrm{~A}_{260}\right)$ using the NanoDrop (ND-1000) spectrophotometer (NanoDrop Technologies) or by b) analysis on $1 \%$ agarose gels and comparison with a known concentration of 100-bp DNA marker (Jena Bioscience, Germany).

\section{DNA digestion}

Genomic DNA ( $5 \mu \mathrm{g})$ was incubated with 10 units each of EcoRI, EcoRV, CfoI, and $X b a \mathrm{I}$ (Boehringer Mannheim, Mannheim, Germany) in the recommended buffer at $37^{\circ} \mathrm{C}$ for 3 h. DNA digestion was assayed by visual inspection after agarose gel electrophoresis. 


\section{PCR assays}

\section{Ribosomal DNA amplification}

The fungal primers of the internal transcribed spacers 3 and 4 (ITS3 and ITS4; White et al., 1990) amplify a region of ribosomal DNA (rDNA) that is common to all fungi. Each $25-\mu \mathrm{L}$ reaction mixture contained buffer [ $(20 \mathrm{mM}$ Tris- $\mathrm{HCl}, \mathrm{pH} 8.4,50 \mathrm{mM} \mathrm{KCl}, 15 \mathrm{mM}$ $\mathrm{MgCl}_{2}, 0.2 \mathrm{mM}$ deoxyribonucleoside triphosphates, $25 \mathrm{pmol}$ of both the primers, $0.5 \mathrm{U}$ Taq DNA polymerase (JenaBioscience) and $5 \mu \mathrm{L}$ DNA sample. Cycling conditions were $95^{\circ} \mathrm{C}$ for $10 \mathrm{~min}$, then 30 cycles at $94^{\circ} \mathrm{C}$ for $30 \mathrm{~s}, 50^{\circ} \mathrm{C}$ for $2 \mathrm{~min}$ and $72^{\circ} \mathrm{C}$ for $2 \mathrm{~min}$.

\section{Universally primed PCR}

Amplification reactions were performed in $0.2-\mathrm{mL}$ microcentrifuge tubes in a $25-\mu \mathrm{L}$ reaction volume containing $10 \mathrm{mM}$ Tris- $\mathrm{HCl}, \mathrm{pH} 8.8,50 \mathrm{mM} \mathrm{KCl}, 0.8 \mathrm{mM} \mathrm{NaCl}, 3.5 \mathrm{mM}$ $\mathrm{MgCl}_{2}, 0.1 \%$ Triton X-100, $0.4 \mathrm{mM}$ dNTPs, 20 pmol for primer L21 or AS4, 1.0 U Taq DNA polymerase (JenaBioscience) and 10 to $15 \mathrm{ng}$ genomic DNA. PCR amplification was performed in a C1000 Thermal Cycler (Bio-Rad Laboratories, CA, USA) programmed for 30 cycles of denaturation at $94^{\circ} \mathrm{C}$ for $30 \mathrm{~s}$ (first denaturation step at $94^{\circ} \mathrm{C}$ for $3 \mathrm{~min}$ ), annealing at $56^{\circ} \mathrm{C}$ for 70 $\mathrm{s}$ and polymerization at $72^{\circ} \mathrm{C}$ for $60 \mathrm{~s}$, with a final extension step of $72^{\circ} \mathrm{C}$ for $5 \mathrm{~min}$. The reaction tubes were held at $4^{\circ} \mathrm{C}$ following the final amplification cycle. Two microliters universally primed PCR (UP-PCR) products (1/10 of the total reaction volume) was electrophoresed on $2 \%$ agarose gel at $150 \mathrm{~V}$ with TAE buffer for $50 \mathrm{~min}$.

\section{Microsatellite-primed PCR}

Microsatellite-primed PCR (MSP-PCR) profiles were generated following the protocol of Abd-Elsalam et al. (2007), using T3B primer (20 pmol per $25-\mu \mathrm{L}$ reaction volume) and extending the elongation step $\left(72^{\circ} \mathrm{C}\right)$ to $2 \mathrm{~min}$. Ten microliters reaction mixture was applied on $1.5 \%(\mathrm{w} / \mathrm{v})$ agarose gels in $0.5 \mathrm{X}$ TBE (Tris-borate EDTA) buffer and the amplicons separated by electrophoresis at $80 \mathrm{~V}$ for $3.5 \mathrm{~h}$. The gels were subsequently stained with ethidium bromide (EtBr) and photographed under ultraviolet light.

\section{RESULTS AND DISCUSSION}

In our laboratories, we perform phylogenic studies on a diverse variety of fungi. Efficient extraction of DNA is required for these studies, but routine DNA extractions often do not work for all fungi. Grinding of frozen or lyophilized mycelium or bead beating work usually for most fungi and require universal DNA extraction methods (Jin et al., 2004). However, for high throughput analysis these methods are labor-intensive and are not suited for analysis of multiple isolates. For DNA extraction typically fungi are grown in liquid shake cultures in Erlenmeyer flasks, Roux bottles or even microtubes (Cenis, 1992). We report here a simple method for culturing Cladosporioid fungi for isolation of DNA that can be completed within three days from start to finish. The growth of mycelia on Petri dishes eliminates the need for still or shaking liquid cultures. Fungal mycelium 
mats $(100 \mathrm{mg}$ ) from 3-day-old colonies grown on duplex agar medium was homogenized by an electric grinder prior to DNA extraction. The resulting medium is not a true solid medium, but rather looks like a dense gel.

The mechanical grinding procedure for isolation of DNA from cells in DNA extracting buffer is very simple and cost effective and it does not need the use of liquid nitrogen, which is often problematic and hazardous, especially when large numbers of samples need to be examined. Motorized pulverization of mycelium generates cell lysates, and often works faster than using cell-wall degrading enzymes or high temperatures (Lugert et al., 2006).

We evaluated the quality of the extracted DNA in a six-step process. The pellets were all colorless and could be dissolved in TE or water. Figure 1 shows the results of the separation of the extracted DNA on a $1.5 \%$ agarose gel, stained with ethidium bromide and visualized under UV light. It shows that our method yields high-quality DNA, which is transparent, non-viscous and lacks visible contamination of RNA. No smearing of DNA occurred on the gel, and the 100-bp DNA marker fragment was clearly visible, indicating that DNA degradation had not occurred.

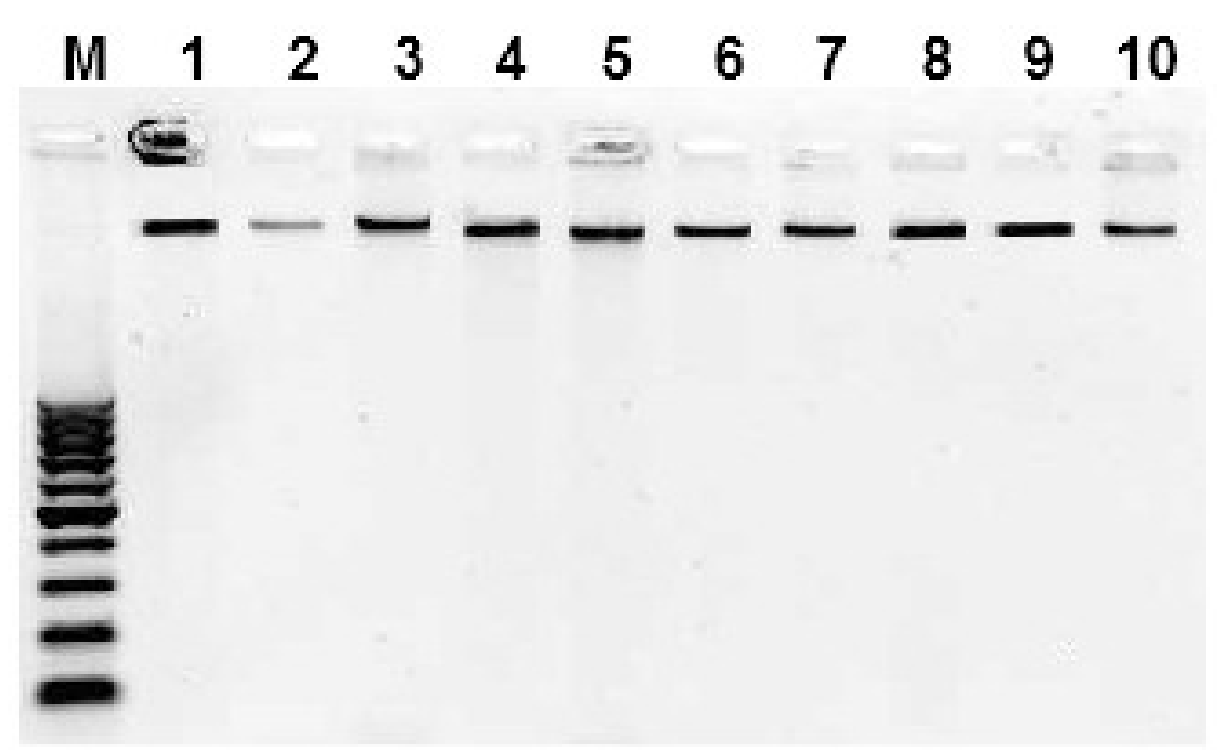

Figure 1. Agarose gel (1.5\%) electrophoresis of undigested genomic DNA isolated from 10 different Cladosporium isolates. For each isolate $10 \mathrm{ng} / \mu \mathrm{L}$ genomic DNA was loaded (lanes 1-10); $\mathrm{M}=100-\mathrm{bp}$ DNA molecular weight ladder. Lane $1=C$. cladosporioides; lane $2=C$. tennuissimum; lane $3=C$. sphaerospermum; lane $4=C$. herbarum; lane $5=C$. herbarum; lane $6=C$. macrocarpum; lane $7=C$. chlamydosporis; lane $8=C$. fulvum; lane $9=$ Cladosporium sp; lane $10=$ Cladosporium $\mathrm{sp}$.

DNA yields from fungal mats using the modified SDS method ranged from 120 to $160 \mu \mathrm{g} / \mathrm{g}$ fresh weight mycelium with an $\mathrm{A}_{260} / \mathrm{A}_{280}$ ratio close to 2.00 and an $\mathrm{A}_{230} / \mathrm{A}_{260}$ ratio around 1.6, indicating very little contamination of the DNA fraction by proteins, polysaccharides or aromatic compounds. Results obtained with the NanoDrop spectrophotometer for the DNA purified by the current method are shown in Table 2. 
Table 2. DNA yield and quality from Cladosporium species as determined by NanoDrop spectrophotometer measurements.

\begin{tabular}{|c|c|c|c|c|}
\hline Strain number & Cladosporium species & $\mathrm{ng} / 2 \mu \mathrm{L}$ & $\mathrm{A}_{260} / \mathrm{A}_{280}$ & $\mathrm{~A}_{230} / \mathrm{A}_{260}$ \\
\hline 1 & C. cladosporioides & 21.63 & 1.93 & 1.81 \\
\hline 2 & C. tennuissimum & 22.93 & 1.93 & 1.79 \\
\hline 3 & C. sphaerospermum & 20.26 & 1.68 & 1.50 \\
\hline 4 & C. herbarum & 20.65 & 1.65 & 1.47 \\
\hline 5 & C. herbarum & 22.44 & 1.65 & 1.45 \\
\hline 6 & C. macrocarpum & 22.19 & 1.66 & 1.36 \\
\hline 7 & C. chlamydosporis & 22.86 & 1.60 & 1.57 \\
\hline 8 & C. fulvum & 23.25 & 1.64 & 1.35 \\
\hline 9 & Cladosporium sp & 22.52 & 1.89 & 1.65 \\
\hline 10 & Cladosporium sp & 23.17 & 1.87 & 1.60 \\
\hline
\end{tabular}

DNA was digested completely with 4 different restriction enzymes (EcoRI, EcoRV, CfoI, and $X b a \mathrm{I}$ ), further confirming the quality of the extracted DNA. Figure 2 gives an example of DNA digested with restriction endonuclease $C f o I$. From these results we conclude that the purity and quality of the isolated genomic DNA was sufficient for efficient digestion by restriction enzymes.

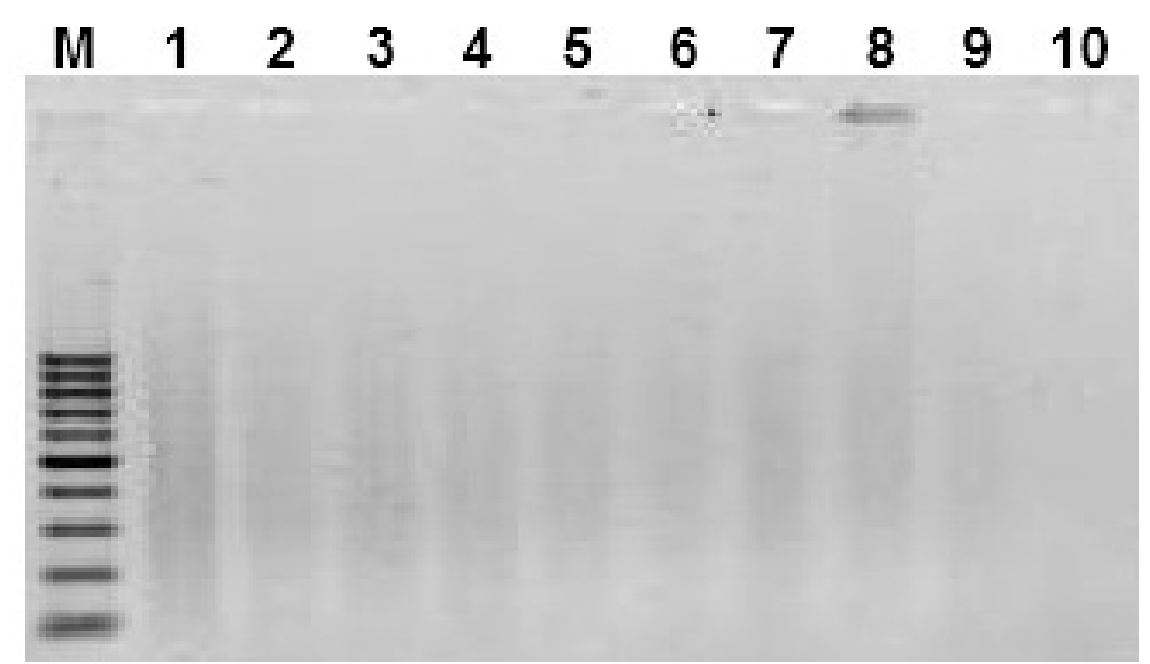

Figure 2. Agarose gel (1.5\%) electrophoresis of genomic DNA digested with the restriction enzyme $C f o \mathrm{I} . \mathrm{M}=$ 100 -bp DNA molecular weight ladder. For identification of lanes, see legend to Figure 1.

The suitability of extracted DNA for additional molecular analyses is shown by performing PCR. All primers tested were shown in Table 3.

\begin{tabular}{llll}
\multicolumn{2}{c}{ Table 3. Primers used to amplify fungal DNA. } & & References \\
\hline Primer code & Sequence & Amplified region & White et al., 1990 \\
\hline ITS3 & 5'-GCA TCG ATG AAG AAC GCA GC G-3' & ITS1 nDNA & Bulat et al., 1998 \\
ITS4 & 5'-TCC TCC GCT TAT TGA TAT GC-3' & & Universally primed-PCR-derived sequence \\
AS4 & 5'-TGT GGG CGC TCG ACA C-3' & Meyer et al., 2001 \\
L21 & 5'-GGA TCC GAG GGT GGC GGT TCT-3' & Microsatellite repeats & M'-AGG TCG CGG GTT CGA ATC C-3' \\
T3B & 5'-ATS
\end{tabular}


From the isolated DNA, the 18S rRNA genes of the ITS regions were amplified. When using the primer pair ITS3/ITS4, a single band of approximately $460 \mathrm{bp}$ was obtained from all isolates studied (Figure 3). All genomic DNA samples obtained from the different isolates showed clear, sharp and reproducible PCR products when primer UP-PCR was used for amplification. UP-PCR products of various sizes, ranging from 200 to $1300 \mathrm{bp}$, were obtained (Figure 4).

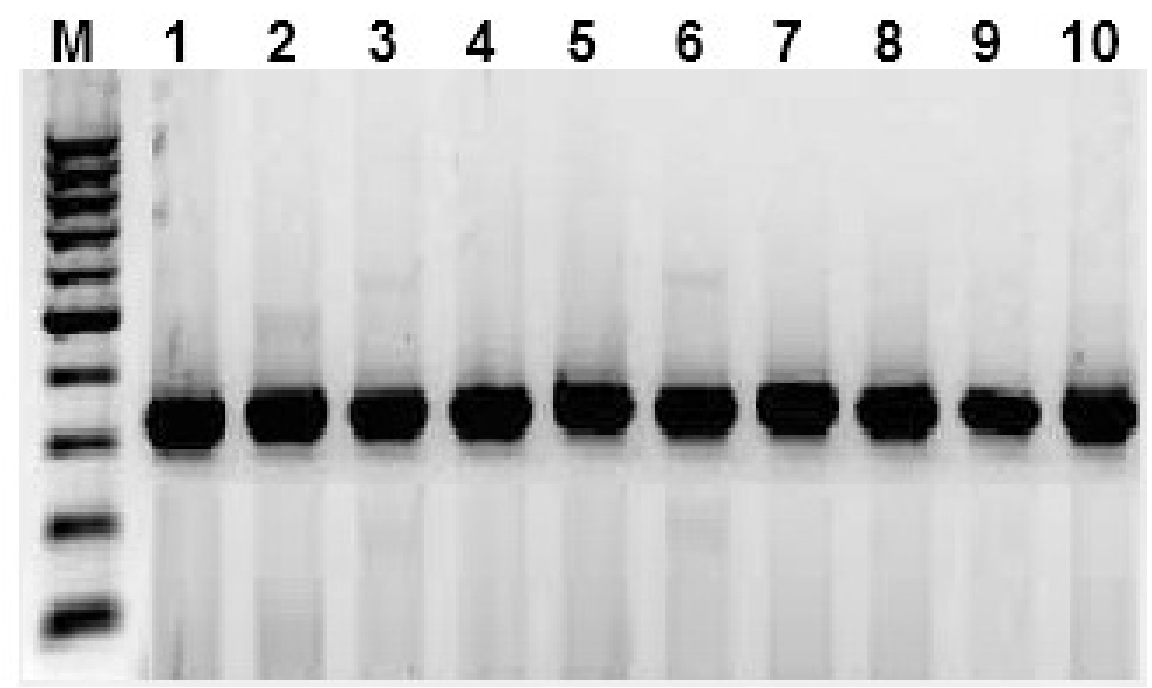

Figure 3. Agarose gel (1.5\%) electrophoresis of the amplified internal transcribed spacer (ITS) products obtained with the ITS3/ITS4 primer pair. M = 100-bp DNA molecular weight ladder. For identification of lanes, see legend to Figure 1.

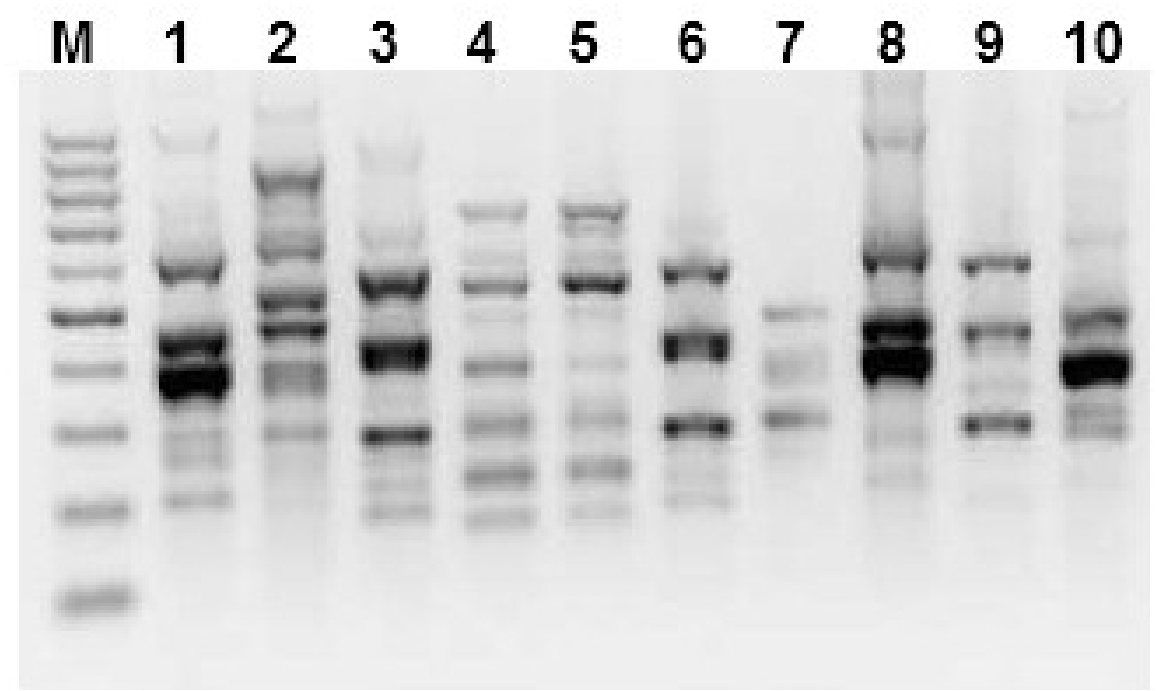

Figure 4. Agarose gel (1.5\%) electrophoresis of universally primed-PCR products obtained by using the L 21 primer. $\mathrm{M}=100$-bp DNA molecular weight ladder. For identification of lanes, see legend to Figure 1. 
DNA was also suitable for MSP-PCR, a technique analogous to MSP-PCR but using the T3B microsatellite core sequence as a unique PCR primer. The microsatellite DNA fragments within the expected range of length (100-1300 bp) were amplified in most cases from all Cladosporium isolates. About two thirds of microsatellites were not polymorphic among the 10 isolates, and could not be used for distinction of Cladosporium species (Figure 5).

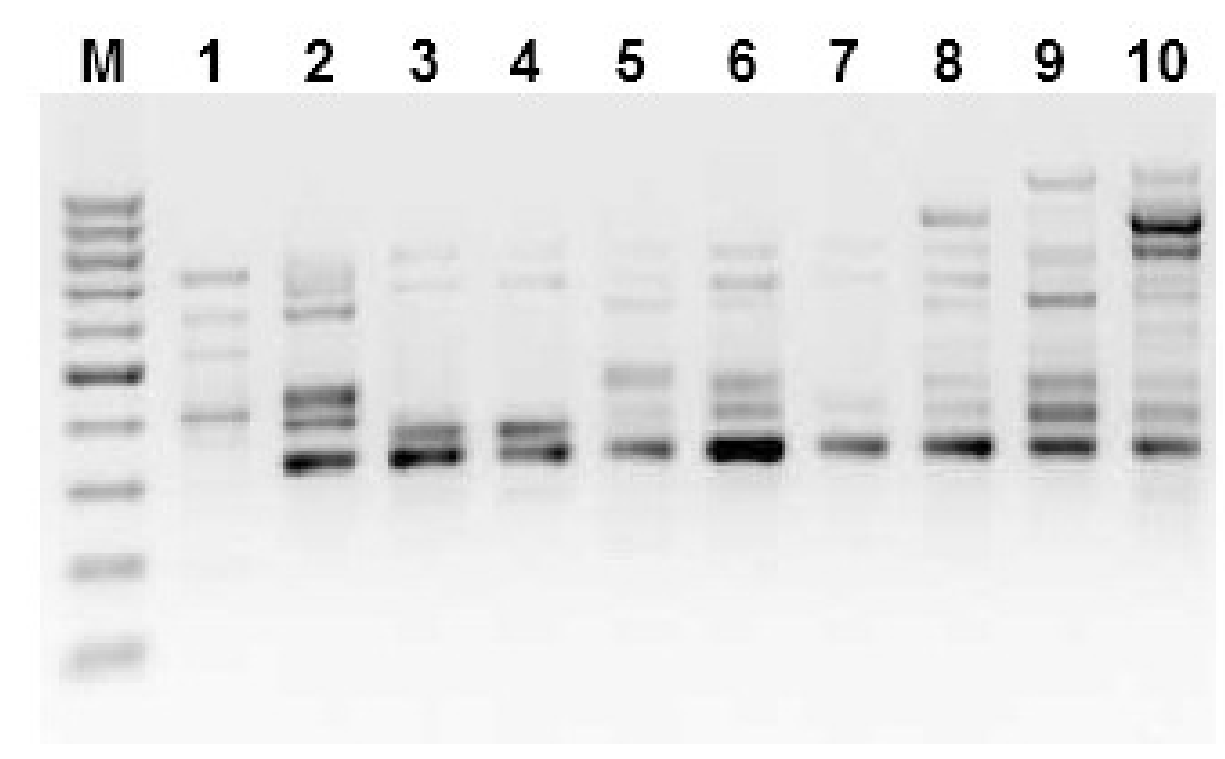

Figure 5. Agarose gel (1.5\%) electrophoresis of the microsatellite-primed PCR products obtained by using the T3B primer. $\mathrm{M}=100$-bp DNA molecular weight ladder. For identification of lanes, see legend to Figure 1.

The DNA isolated from all Cladosporium isolates generated reproducible PCR amplification products that were well resolved on $1.5 \%$ agarose gels. This further confirmed that the isolated DNA was free of polysaccharide and polyphenols, which are known to inhibit Taq DNA polymerase and restriction endonucleases (Moyo et al., 2008). RNA can be removed by incubation with RNase A, either after the nucleic acids have been extracted or by inclusion in the extraction buffer (Abd-Elsalam et al., 2007). Pure DNA eluted from the agarose gels ensures reliable DNA amplification by PCR. Our method does not require liquid nitrogen or expensive commercial DNA extraction kits, which significantly decreases costs and time for DNA analysis. The growth of the fungus for only a few days before DNA extraction also facilitates homogenization and disruption of mycelium as it is not yet melanized. The time required for our DNA extraction method is less than $60 \mathrm{~min}$, which is fast when compared with other genomic DNA extraction methods described. Our extraction method generated DNA that can be used in various molecular analyses. The method is especially useful in laboratories that lack the facilities to work with liquid nitrogen. We will use the method to further analyze global populations of C. fulvum and other Cladosporium species in the future. 


\section{ACKNOWLEDGMENTS}

The authors gratefully acknowledge financial support from Distinguished Scientist Fellowship Program (DSFP), King Saud University.

\section{REFERENCES}

Abd-Elsalam KA, Asran-Amal A and El-Samawaty A (2007). Isolation of high quality DNA from cotton and its fungal pathogens. J. Plant Dis. Prot. 114: 113-116.

Bulat SA, Lübeck M, Mironenko N, Jensen DF, et al. (1998). UP-PCR analysis and ITS1 ribotyping of strains of Trichoderma and Gliocladium. Mycol. Res. 102: 933-943.

Cenis JL (1992). Rapid extraction of fungal DNA for PCR amplification. Nucleic Acids Res. 20: 2380.

Ghahfarokhi MS, Fazli A, Lotfi A and Abyane MR (2004). Cellobiose dehydrogenase production by the genus Cladosporium. Iran. Biomed. J. 8: 107-111.

Griffin DW, Kellogg CA, Peak KK and Shinn EA (2002). A rapid and efficient assay for extracting DNA from fungi. Lett. Appl. Microbiol. 34: 210-214.

Jin J, Lee YK and Wickes BL (2004). Simple chemical extraction method for DNA isolation from Aspergillus fumigatus and other Aspergillus species. J. Clin. Microbiol. 42: 4293-4296.

Karakousis A, Tan L, Ellis D, Alexiou H, et al. (2006). An assessment of the efficiency of fungal DNA extraction methods for maximizing the detection of medically important fungi using PCR. J. Microbiol. Methods 65: 38-48.

Loeffler J, Hebart H, Cox P, Flues N, et al. (2001). Nucleic acid sequence-based amplification of Aspergillus RNA in blood samples. J. Clin. Microbiol. 39: 1626-1629.

Lugert R, Schettler C and Gross U (2006). Comparison of different protocols for DNA preparation and PCR for the detection of fungal pathogens in vitro. Mycoses 49: 298-304.

Meyer W, Maszewska K and Sorrell TC (2001). PCR fingerprinting: a convenient molecular tool to distinguish between Candida dubliniensis and Candida albicans. Med. Mycol. 39: 185-193.

Moyo M, Amoo SO, Bairu MW, Finnie JF, et al. (2008). Optimizing DNA isolation for medicinal plants. South Afr. J. Bot. 74: 771-775.

Pitkäranta M, Meklin T, Hyvarinen A, Paulin L, et al. (2008). Analysis of fungal flora in indoor dust by ribosomal DNA sequence analysis, quantitative PCR, and culture. Appl. Environ. Microbiol. 74: 233-244.

Qiu-Xia C, Chang-Xing L, Wen-Ming H, Jiang-Qiang S, et al. (2008). Subcutaneous phaeohyphomycosis caused by Cladosporium sphaerospermum. Mycoses 51: 79-80.

Rogers SO (1994). Phylogenetic and Taxonomic Information from Herbarium and Mummified DNA. In: Conservation of Plant Genes II: Utilization of Ancient and Modern DNA. Monographs in Systematic Botany 48 (Miller JS, Golenberg EM and Adams JE, eds.). Missouri Botanical Garden, St. Louis.

Schubert K (2005). Morphotaxonomic Revision of Foliicolous Cladosporium species (Hyphomycetes). PhD thesis, Martin-Luther-University, Halle-Wittenberg.

Sharma R, Mahla HR, Mohapatr T, Bhargava SC, et al. (2003). Isolating plant genomic DNA without liquid nitrogen. Plant Mol. Biol. Rep. 21: 43-50.

White TM, Bruns T, Lee S and Taylor J (1990). Amplification and Direct Sequencing of Fungal Ribosomal RNA for Phylogenetics. In: PCR Protocols: A Guide to Methods and Applications (Innis MA, Gelfand DH, Sninsky JJ and White TJ, eds.). Academic Press, San Diego, 315-321.

Williamson EC, Leeming JP, Palmer HM, Steward CG, et al. (2000). Diagnosis of invasive aspergillosis in bone marrow transplant recipients by polymerase chain reaction. Br. J. Haematol. 108: 132-139.

Wong SF, Mak JW and Pook PC (2007). New mechanical disruption method for extraction of whole cell protein from Candida albicans. Southeast Asian J. Trop. Med. Public Health 38: 512-518.

Yano S, Koyabashi K and Kato K (2003). Intrabronchial lesion due to Cladosporium sphaerospermum in a healthy, nonasthmatic woman. Mycoses 46: 348-350.

Yeo SF and Wong B (2002). Current status of nonculture methods for diagnosis of invasive fungal infections. Clin. Microbiol. Rev. 15: 465-484. 